\title{
Taxonomic studies of Amanita muscaria (L.) Lam (Amanitaceae, Agaricomycetes) and its infraspecific taxa in Brazil
}

Felipe Wartchow ${ }^{1,3}$, Leonor Costa Maia ${ }^{2}$ and Maria Auxiliadora de Queiroz Cavalcanti ${ }^{2}$

Submitted: 27 April, 2012. Accepted: 1 October, 2012

\begin{abstract}
We analyzed specimens identified as Amanita muscaria, some recently collected and others already deposited in herbaria, in Brazil. We concluded that two subspecies of A. muscaria occur in Brazil: A. muscaria var. muscaria; and A. muscaria var. flavivolvata. The first taxon was found in association with Castanea sativa, and the second (one specimen only) was found in association with Pinus and Eucalyptus spp. Morphologically, A. muscaria var. flavivolvata is distinguished by a shallower subhymenium and by basidiospores that are more elongated than are those of $A$. muscaria var. muscaria, which is the more widely known subspecies. We present descriptions, discussions, illustrations and a dichotomous key for these two subspecies.
\end{abstract}

Key words: Agaricales, Basidiomycota, Mushroom, taxonomy

\section{Introduction}

Amanita muscaria, in a broad sense, is considered the world's most famous fungal species, often depicted in various media (Michelot \& Melendez-Howell 2003). This species is referenced in relation to several ancient Old and New World cultures (Brough 1971, Dunn 1974; Lowy 1974; Whelan 1974; Saar 1991; Samorini 1992; Hajicek-Dobberstein 1995) and has been reported to cause psychosis in humans (Lampe 1979; Satora et al. 2005; Brvar et al. 2006), owing to the psychoactive compounds it contains, including muscimol (Wieland, 1968; Krogsgaard-Larsen et al. 1981; Stijve \& Meijer 1993; Michelot \& Melendez-Howell 2003; Tsujikawa et al. 2007). There have also been reports of $A$. muscaria-related accidents involving pets (Rossmeisl et al. 2006).

Initially, A. muscaria was suspected to be a well-defined morphospecies with ample geographic distribution, also associated with ectomycorrhizal hosts dispersed across multiple genres of vascular plants (Trappe 1962). However, phylogenetic studies conducted by Oda et al. (2004) showed that $A$. muscaria occurring in Eurasia and North America correspond to phylogenetically distinct populations. Later, Geml et al. $(2006,2009)$ found that it is likely that cryptic, sympatric speciation occurred in the Beringia region of what is now Alaska, and Geml et al. (2008) concluded that $A$. muscaria sensu lato has a strong inter- and intra-continental phylogeographic structure, mainly in North America, and that several phylogenetic species occur within A. muscaria sensu lato. The distribution of the species is listed by Tulloss \& Yang (2012).

As a continuation of studies on the genus Amanita conducted by our group (Wartchow \& Maia 2007; Wartchow et al., 2007, 2009, 2013), the present study raises the possibility of the occurrence of various distinct subspecies of A. muscaria in Brazil. We also address morphological studies, as well as discussing the importance of using morphological and ecological criteria in order to distinguish between subspecies.

\section{Materials and Methods}

In May 2009, fresh A. muscaria specimens were collected in the São Francisco de Paula National Forest (29 $23^{\prime}$ 'S; $\left.50^{\circ} 23^{\prime} \mathrm{W}\right)$, which covers an area of 1606 ha in the state of Rio Grande do Sul, Brazil. Although the composition of this nature reserve is classified as a mixed ombrophilous forest, there are also exotic plantation species of Pinus, Eucalyptus and Castanea sativa Mill. (Dobrovolski et al. 2006; Longhi et al. 2006, Ribeiro et al. 2007). Other materials examined were obtained from the collections of the herbaria of the following institutions (Thiers 2012): the Federal University

\footnotetext{
${ }^{1}$ Universidade Federal da Paraíba, Departamento de Sistemática e Ecologia, João Pessoa, PB, Brazil

${ }^{2}$ Universidade Federal de Pernambuco, Departamento de Micologia, Recife, PE, Brazil

${ }^{3}$ Author for correspondence: fwartchow@yahoo.com.br
} 
of Santa Catarina (code, FLOR); the Blumenau Regional University Foundation (code, FURB); the University of Santa Cruz do Sul (code, HCB); the Federal University of Santa Maria (code, SMDB); the São Paulo State Department of the Environment (code, SP); and the Federal University of Pernambuco (code, URM).

The description of basidiospores observes the notation " $[a / b / c]$ ", which is read as " $a$ (number of) basidiospores were measured for $b$ (number of) basidiomata from $c$ (number of) collections". Data related to size and shape (Q) were annotated as " $(m-) n-o(-p)$ ", where $m$ and $p$ are the lowest and highest value (observed or calculated), respectively; $n$ is the 5th percentile; and $o$ is the 95th percentile. The descriptions of basidiospores also consider the following biometric variables (Tulloss et al. 1992; Tulloss 2000; Tulloss \& Lindgren 2005):

$\mathbf{L}=$ the average length of basidiospores of a single basidiome

$\mathbf{W}=$ the average width of basidiospores of a single basidiome

L' = the average length of all basidiospores

$\mathbf{W}^{\prime}=$ the average width of all basidiospores

$\mathrm{Q}=$ ratio of length to width (for a single basidiospore)

$\mathbf{Q}=$ the mean $\mathrm{Q}$ computed for all basidiospores of one basidiome

$Q^{\prime}=$ the mean $\mathrm{Q}$ computed for all basidiospores of all basidiomes

$\mathbf{w}_{\mathrm{sc}}=$ width of the central stratum of the lamella

$\mathbf{w}_{\mathrm{st}}$-near = distance from one side of the central stratum to the base of the nearest basidium

$\mathbf{w}_{\text {st }}$-far = distance from one side of central stratum to the base of the farthest basidium

Abbreviations in author citations follow Kirk \& Ansell (1992). The infrageneric classification follows the proposal made by Corner \& Bas (1962), subsequently revised by Bas (1969), and later modified by Yang (1997).

\section{Results and Discussion}

Amanita muscaria var. muscaria (L.) Lam., Encycl. Méth. Bot. 1: 111. 1783

$\equiv$ Agaricus muscarius L., Sp Pl. 2: 1172. 1753.

$\equiv$ Hypophyllum muscarius (L.) Paulet nom. inval., Hist.

Soc. Roy. Med. T.11, f. 2-3. 1779 ('1776').

$\equiv$ Agaricus muscarius L.: Fr, Syst.Mycol. 1:16. 1821.

$\equiv$ Venenarius muscarius (L.: Fr) Earle, Bull. New York.

Bot. Garden 5: 450. 1909.

= Agaricus imperialis Batsch, Elench. fung. (Halle): col. 59. no. 55. 1783.

= Agaricus puellus Batsch, Elench. fung. col. 59, no. 54 . 1783 .

三Amanita muscaria var. puella (Batsch) Pers., Syn. Meth, Fung. 2: 253.1801.

= Agaricus pseudoaurantiacus Bull. Herb. France 11: pl. 122. 1794.
Amanita muscaria var. muscaria (L.) are medium-to-large basidiomycetes, dispersed across the ground.

> Pileus: 70.0-140.0 (-180.0) mm; evolving from hemispheric to flat and eventually becoming plano-concave; dark red, then fading to pale orange; thinly striated margin, 10.0-20.0 mm long; invariably white context, approximately $10.0 \mathrm{~mm}$ thick at the center and tapering toward the edges; universal veil with invariably pyramidal whitish to cream-colored warts, moderately easy to remove

$>$ LAMELLAE: closely spaced in younger basidia, forming a decurrent line at the apex of the stipe in older individuals and eventually separating, invariably white to creamy-white out to the edges, $16.0 \mathrm{~mm}$ wide, proximal; lamellulae truncate to obtusely truncate, varying in length

$>$ STIPE: $8.0-22.0 \times 75.0-150.0 \mathrm{~mm}$, narrowing toward apex, invariably white, fine longitudinal ridges (observed only with $\mathrm{a} \geq 10 \times$ lens); bulb $35.0-45.0 \mathrm{~mm}$ in length and 25.0-40.0 $\mathrm{mm}$ in width, fusoid; invariably white background, solid, central cylinder $10.0 \mathrm{~mm}$ diameter, insect or larva tunnels of reddish brown (salmon colored), partial veil white near the midpoint, smooth, with remnants of universal veil on margins; universal veil distributed as submembranous sheaths broken at stipe base and at bulb

$>$ ODor: undetectable

$>$ Flavor: undetectable

$>$ BASIDIOSPORES: [100/4/1] (8.5-) 9.0-12.2 (-13.0) $\times$ (5.7-) 6.5-9.3 (-9.4) $\mu \mathrm{m},\left(\mathbf{L}=(9.3-)\right.$ 10.1-10.9 $\mu \mathrm{m}, \mathbf{L}^{\prime}$ $=10.2 \mu \mathrm{m}, \mathbf{W}=(6.9-) 7.6-8.3 \mu \mathrm{m}, \mathbf{W}^{\prime}=7.6 \mu \mathrm{m}, \mathbf{Q}=$ (1.17-) 1.21-1.50 (-1.63), $\left.\mathbf{Q}=1.33-1.37, \mathbf{Q}^{\prime}=1.35\right)$, inamyloid, hyaline, typically ellipsoid, rarely elongated, smooth, thin-walled; apiculus obtuse, conical sublateral; containing a large guttula

$>$ BASIDIA: $55.0-65.0 \times 10.0-13.0 \mu \mathrm{m}$, bearing four sterigmata, each $4.0 \mu \mathrm{m}$ in length, abundant clamp connections

> SubHYMENiUm: rehydrating satisfactorily; approximately $40.0 \mu \mathrm{m}$ thick, three cells deep; generally inflated and clavate; approximately $19.0 \times 13.0 \mu \mathrm{m} ; \mathbf{w}_{\mathrm{st}}$-near $=$ $110.0-125.0 \mu \mathrm{m} ; \mathbf{w}_{\mathrm{st}}$ - $\mathbf{f a r}=130.0-145.0 \mu \mathrm{m}$

$>$ LAMELLA TRAMA: rehydrating satisfactorily; $\mathbf{w}_{\mathrm{cs}}=$ 40.0-70.0 $\mu \mathrm{m}$; filamentous hyphae 4.0-7.5 $\mu \mathrm{m}$, sometimes branched, with frequent clavate elements approximately $115.0 \times 36.0 \mu \mathrm{m}$; absent vascular hyphae

$>$ LAMELLAR EDGE: elements not found

$>$ Pileus CONTEXT: rehydrating satisfactorily, distinctly acrophysalidic; acrophysalides approximately $150.0 \times$ $30.0 \mu \mathrm{m}$ clavate and elongated, abundant; filamentous hyphae 3.0-8.0 $\mu \mathrm{m}$, very common, usually branched, very intertwined, forming a loose matrix where the other elements occur; vascular hyphae not observed.

> STIPE CONTEXT: rehydrating satisfactorily; longitudinally acrophysalidic; acrophysalides $300.0 \times 40.0$ 
$\mu \mathrm{m}$, abundant; filamentous hyphae 2.0-9.0 (-20.0) $\mu \mathrm{m}$, longitudinally oriented but sometimes branched, abundant; vascular hyphae 5.0-20.0 $\mu \mathrm{m}$ with a more or less longitudinal orientation, abundant

> Pileipellis: cutis reaching $240.0 \mu \mathrm{m}$ in the center; suprapellis an 80.0- $\mu \mathrm{m}$ thick ixocutis with 2.0-6.0 $\mu \mathrm{m}$ intertwined hyphae, hyaline, embedded in a gelatinous layer; subpellis $(160.0 \mu \mathrm{m})$ a cutis, radially arranged, 2.0-5.0 $\mu \mathrm{m}$ hyphae, abundant, yellowish; vascular hyphae of approximately $10.0 \mu \mathrm{m}$, rare

$>$ Universal VeIL:

- on pileus-terminal elements primarily balloon-shaped, $40.0 \times 25.0 \mu \mathrm{m}$, pale, abundant, sometimes thick-walled, occasionally in chains of two cells; filamentous hyphae $(1.5-5.0 \mu \mathrm{m})$, often branched, pale, thin-walled, more abundant near the surface of the pileus; vascular hyphae not observed

- on stipe base-inflated cells, typically subglobose $(41.0 \times 40.0 \mu \mathrm{m})$, sometimes ovoid $(44.0 \times$ $34.0 \mu \mathrm{m})$, elliptical $(50.0 \times 40.0 \mu \mathrm{m})$, or clavate $(60.0 \times 25.0 \mu \mathrm{m})$, pale, $1.0-\mu \mathrm{m}$ thick walls, filamentous hyphae of approximately 2.0-8.0 $\mu \mathrm{m}$, hyaline, abundant; vascular hyphae absent Partial veiL: intensely intertwined, branched filamentous hyphae of 2.0-4.0 $\mu \mathrm{m}$, abundant; elongate-elliptical inflated terminal elements (60.0-92.0 $\times$ 14.0-19.0 $\mu \mathrm{m}$ ), difficult to locate; vascular hyphae absent; margin with abundant inflated cells from the universal veil mixed with hyphae, hyaline

Distribution in Brazil: Rio Grande do Sul (state)

Habitat: on soil under Castanea sativa Mill. (European chestnut)

Material examined: BRAZIL. Rio Grande do Sul: São Francisco de Paula National Forest, 19/V/2009, F. Wartchow FLONA2 (URM 82985).

Comments: The European subspecies is very similar to A. muscaria var. flavivolvata, which differs by having basidiospores that are more elongated, often $\mathbf{L}^{\prime}=10.7$ $\mu \mathrm{m}$ and $\mathbf{Q}^{\prime}=1.42$, and shallower subhymenium with $\mathbf{w}_{\mathrm{st}}{ }^{-}$ near $=75.0-90.0 \mu \mathrm{m}$ and $\mathbf{w}_{\text {st }}$-far $=80.0-105.0(-115.0) \mu \mathrm{m}$ (Tulloss \& Yang 2012). Data on basidiospores provided by Tulloss \& Yang (2012) and Tulloss (unpublished data) for A. muscaria var. muscaria: [475/24/19] (7.4-) 8.5-11.5 $(-13.1) \times(5.6-)$ 6.5-8.5 (-9,8) $\mu \mathrm{m}, \mathrm{L}=(8.7-)$ 9.1-11.2 (-11.4) $\mu \mathrm{m}, \mathbf{L}^{\prime}=10.0 \mu \mathrm{m}, \mathbf{W}=(6.5-) 6.9-8.1 \mu \mathrm{m},(-8.2), \mathbf{W}^{\prime}=7.5$ $\mu \mathrm{m}, \mathrm{Q}=(1.10-)$ 1.21-1.47 (-1.75), $\mathrm{Q}=1.26-1.41(-1.42)$, $\mathbf{Q}^{\prime}=1.34$. Also described for the European taxon $\mathbf{w}_{\mathrm{st}}$-near $=110.0-125.0 \mu \mathrm{m}$ and $\mathbf{w}_{\mathrm{st}}$-far $=130.0-145.0 \mu \mathrm{m}$, similar to measurements reported previously. Another feature is the natural geographic distribution of taxa, A. muscaria var. flavivolvata being found in North America, whereas the natural distribution of $A$. muscaria var. muscaria is in Eurasia.
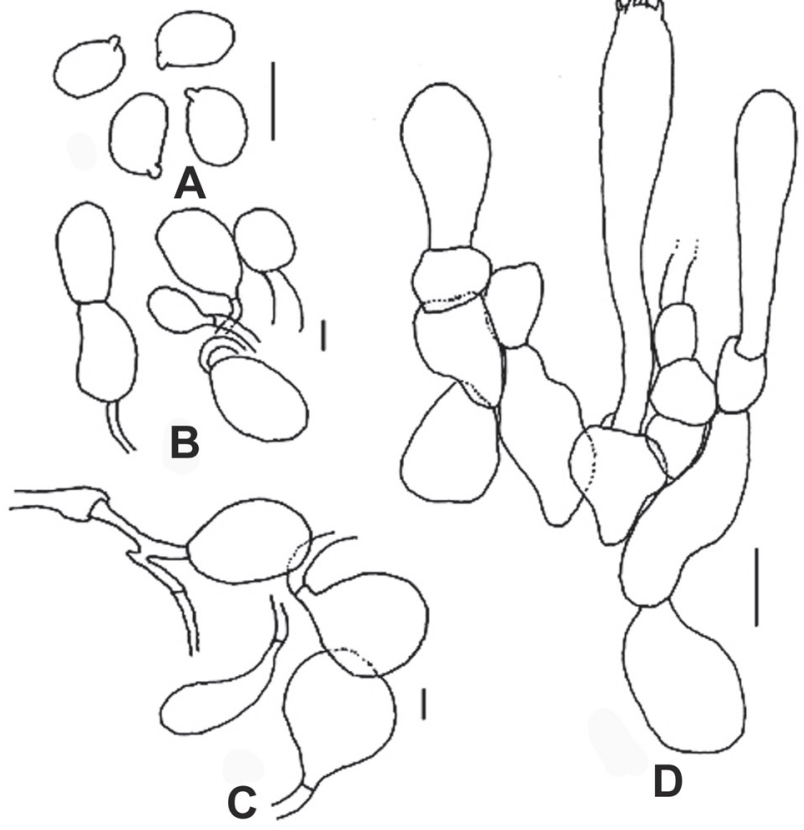

Figure 1. Amanita muscaria var. muscaria. A, basidiospores; B, elements of universal veil on pileus; $\mathbf{C}$, elements of universal veil on stipe base; $\mathbf{D}$, hymenium and subhymenium. Bar $=10 \mu \mathrm{m}$.

In comparison with that of the material studied by Tulloss \& Yang (2012), the $\mathbf{L}$ ' value of the material analyzed here was $2 \%$ higher $(10.0 \mu \mathrm{m}$ vs. $10.2 \mu \mathrm{m})$. It is noteworthy that we measured only 100 basidiospores from a single collection, and one of the basidiomes showed an $\mathbf{L}$ of $10.9 \mu \mathrm{m}$, which contributed to increasing the $\mathbf{L}$ ' value. That basidiome was probably dehydrated at the beginning of sporulation (Tulloss, personal communication).

Geml et al. $(2006,2009)$ were the first to suspect a cryptic speciation in A. muscaria sensu lato, with the dispersion center located in Alaska, USA, in a region known as Beringia. In other studies, Geml et al. (2008) analyzed a larger sample and recognized at least six phylogenetically distinct clades (I to VI), which might represent distinct phylogenetic species. A. muscaria var. muscaria probably corresponds to clade II, with distribution from Eurasia to Alaska and the Pacific Northeastern region of the United States; in temperate, boreal and coastal forests with various species of conifers and deciduous trees, relatively common in Europe (Beardslee 1905; Jenkins \& Petersen 1976; Breitenbach \& Kränzlin 1995; Mattock 1995, Castro 1996; Neville \& Poumarat 2001, 2004; Vaasma 2009). For other parts of the world, this taxon certainly corresponds to material collected from exotic plantations, growing under Pinus and other tree species (e.g., Quercus, Picea and Pseudoptsuga) imported from Europe to Tanzania (Härkönen et al. 1994, Tulloss personal communication), Australia (Reid 1979; Grgurinovic 1997, Wood 1997; Hawkeswood 2006; Robinson 2010), South Africa (Pearson 1950; Reid \& Eicker 1991) and New Zealand (Stevenson 1962; Ridley 1991). In 

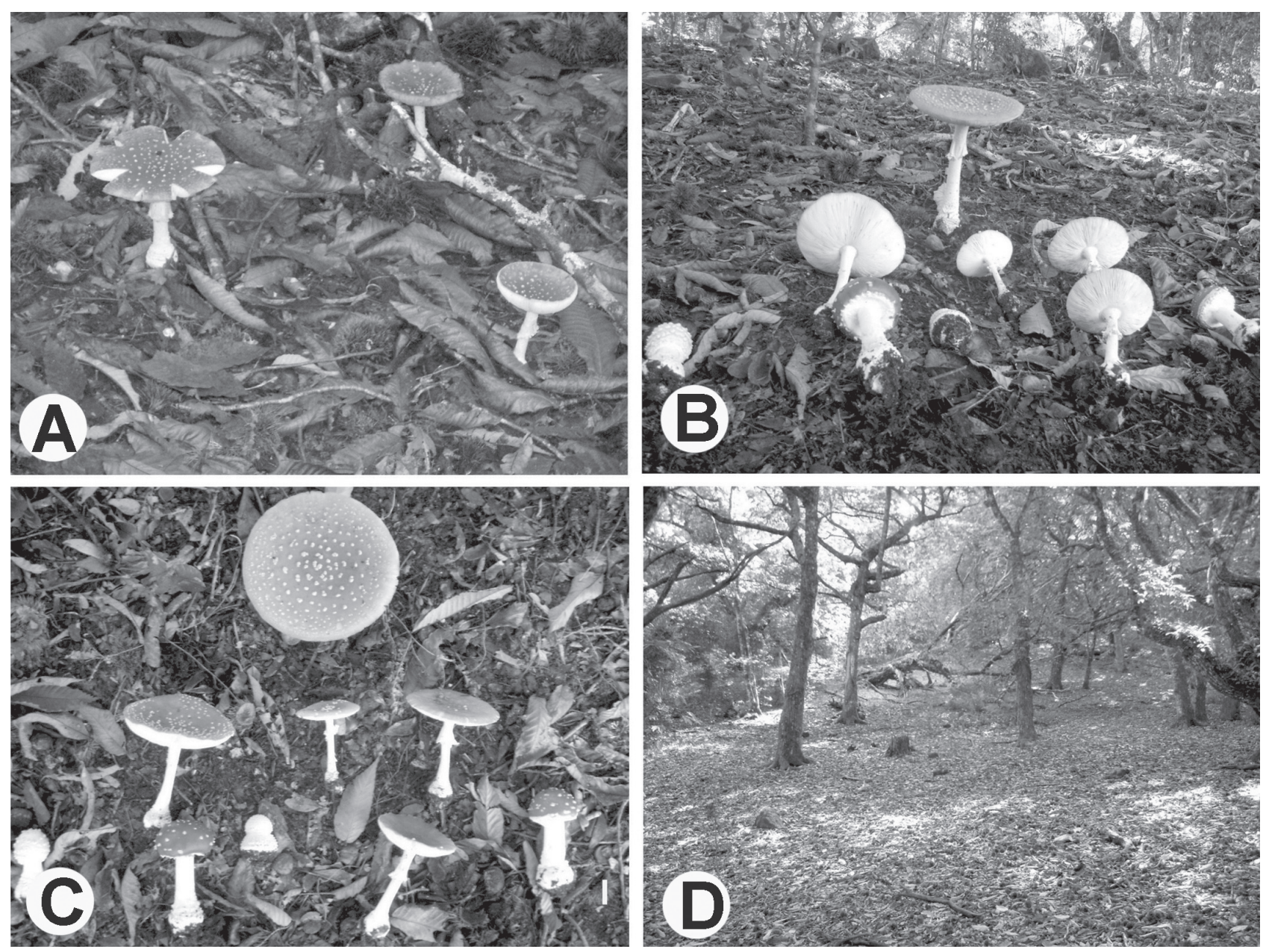

Figure 2. Amanita muscaria var. muscaria. A-C, basidiomes; D, aspect of Castanea sativa plantation. Photographs: F. Wartchow. Bar $=20 \mathrm{~mm}$.

Brazil, this taxon is reportedly found in the plateau region of Rio Grande do Sul among the "European pines" planted there (Homrich 1965). Unfortunately, we could not locate the material needed in order to determine the true identity of this specimen.

The material examined, which was found growing under a Pinus sp. in the state of Santa Catarina [BRAZIL, Santa Catarina, Rancho Queimado, Campinho, 18.v.1986, F. Brugermann (no number) (FLOR 10328)], was very poorly preserved with few basidiospores: [19/1/1] (7.3-) 7.7-9 $\times$ 5.5-6.5 (-6.8) $\mu \mathrm{m},(\mathbf{L}=8.3 \mu \mathrm{m} ; \mathbf{W}=6.1 \mu \mathrm{m} ; \mathrm{Q}=(1.14-)$ 1.20-1.46 (-1.49), $\mathbf{Q}=1.36$. Although the characteristics of the subhymenium and the lamella trama are impossible to analyze, the values found for the basidiospores are characteristic of A. muscaria var. muscaria.

Amanita muscaria var. flavivolvata Singer, Sydowia 11: 374.1957 ('1958'). $\equiv$ Amanita muscaria var. flavivolvata (Singer) Dav.T. Jenkins, Biblioth. Mycol. 57: 56. 1977.

Amanita muscaria var. flavivolvata (Singer) are medium-to-large basidiomycetes.
$>$ Pileus: $70.0-110.0 \mathrm{~mm}$, plano-convex expanding to plano-concave, dark red, becoming paler and eventually orange, shiny surface, slightly viscid, finely striated margin, reaching $11.0 \mathrm{~mm}$ in length; invariably white context, approximately $10.0 \mathrm{~mm}$ thick at the center and gradually tapering toward the margin and eventually tapering more abruptly in the furrows; universal veil invariably with white pyramidal warts that are moderately easy to remove

$>$ LAMELLAE: ranging from closely spaced to completely separated, forming a decurrent line at the apex of the stipe in older individuals, invariably white from edge to edge, $10.0 \mathrm{~mm}$ wide, proximal; lamellulae truncate to obtusely truncate, varying in length

$>$ STIPE: $80.0-100.0 \times 25.0-30.0 \mathrm{~mm}$, narrowing toward apex, invariably white, longitudinally thinly fibrillose (seen only with $\mathrm{a} \geq 10 \times$ lens); bulb from $20.0-50.0 \mathrm{~mm}$ in length and 25.0-40.0 mm in width, fusoid; context white, unchanging, solid, central cylinder $10.0 \mathrm{~mm}$ diameter., insect or larva tunnels of reddish brown (salmon colored); partial veil white near the midpoint, smooth with remnants of universal veil on the edge; 
universal veil whitish, distributed as submembranous sheaths broken at stipe base and bulb

$>$ ODOR: undetectable

$>$ Flavor: undetectable

$>$ BASIDIOSPORES: [295/10/8] (8.2-) 8.5-13.7 (-14.0) $\times$ (5.5-) 6.0-9.5 (-10.0) $\mu \mathrm{m},\left(\mathbf{L}=(10.0-)\right.$ 10.3-11.1 $\mu \mathrm{m}, \mathbf{L}^{\prime}$ $=10.7 \mu \mathrm{m}, \mathbf{W}=7.1-7.8(-8.1) \mu \mathrm{m}, \mathbf{W}^{\prime}=7.6 \mu \mathrm{m}, \mathrm{Q}=$ (1.21-) 1.22-1.71 (-2.00), $\mathbf{Q}=(1.35-)$ 1.41-1.48, $\mathbf{Q}^{\prime}=$ 1.43), inamyloid, hyaline, ellipsoid, sometimes ellipsoid and elongated, occasionally cylindrical, smooth, thin-walled; apiculus obtuse conical, sublateral to subapical; containing a large guttula.

$>$ BASIDIA: $41.0-47.0 \times 11.0-13.0 \mu \mathrm{m}$, two to four sterigmata, each approximately $4.0 \mu \mathrm{m}$, abundant clamp connections

> Subhymenium: rehydrating satisfactorily in most basidiomes; $29.0 \mathrm{~mm}$ thick, three cells deep, generally inflated, either clavate $(13.0-23.0 \times 7.5-16.0 \mu \mathrm{m})$ or elongate $(14.0-20,0 \times 5.0-8.5 \mu \mathrm{m}) ; \mathbf{w}_{\mathrm{st}}$-near $=70.0-$ $90.0 \mu \mathrm{m} ; \mathbf{w}_{\mathrm{st}}-\mathbf{f a r}=80.0-100.0(-115.0) \mu \mathrm{m}$

$>$ LAMELLAE TRAMA: rehydrating satisfactorily in most basidiomes; $\mathbf{w}_{\mathrm{st}}=35.0-70.0 ; \mu \mathrm{m}$ filamentous hyphae 4.0-7.5 $\mu \mathrm{m}$, sometimes branched, with frequent clavate elements $85.0 \times 25.0 \mu \mathrm{m}$; vascular hyphae absent

$>$ LAMELLAR EDGE: elements not observed

$>$ Pileus Context: rehydrating satisfactorily, distinctly acrophysalidic; acrophysalides approximately $180.0 \times$ $20.0 \mu \mathrm{m}$ elongated and clavate, abundant; filamentous
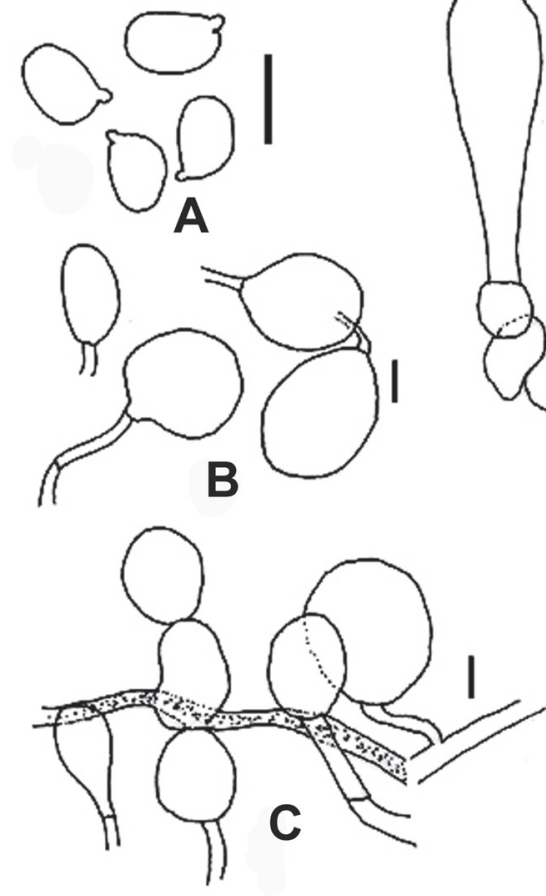

Figure 3. Amanita muscaria var. flavivolvata. A, basidiospores; B, elements of universal veil on stipe base; $C$, elements of universal veil on pileus; $D$, hymenium and subhymenium. Scale bar $=10 \mu \mathrm{m}$. hyphae 2.0-12.0 $\mu \mathrm{m}$, very common, usually branched, very intertwined, forming a loose matrix where other elements occur; vascular hyphae $14.0 \mu \mathrm{m}$, occasional

> STIPE CONTEXT: rehydrating satisfactorily; longitudinally acrophysalidic; acrophysalides $325.0 \times 40.0$ $\mu \mathrm{m}$, abundant; filamentous hyphae 2.0-9.0 (-20.0) $\mu \mathrm{m}$, longitudinally oriented, but sometimes branched, plentiful; vascular hyphae 5.0-13.0 $\mu \mathrm{m}$ with longitudinal orientation, quite abundant

$>$ PILEIPELlis: cutis reaching $170.0 \mu \mathrm{m}$ at the center; suprapellis a 70.0- $\mu \mathrm{m}$ thick ixocutis with 1.5-4.0 $\mu \mathrm{m}$ intertwined hyphae, hyaline, embedded in a gelatinous layer; subpellis a $100.0-\mu \mathrm{m}$ thick cutis, 2.0-4.5 $\mu \mathrm{m}$ hyphae radially arranged and sometimes intertwined, abundant, yellowish; vascular hyphae $10.0 \mu \mathrm{m}$, occasional

$>$ UNIVERSAL VEIL:

- on pileus-terminal elements primarily balloon-shaped $(60.0 \times 43.0 \mu \mathrm{m})$ to subglobose $(30.0 \times 26.0 \mu \mathrm{m})$, pale to hyaline, abundant, sometimes thick-walled, occasionally in chains of two to three cells; filamentous hyphae (1.5-5.0 $\mu \mathrm{m})$, often branched, pale, thin-walled, more abundant near pileus surface; vascular hyphae not observed in most specimens, abundant in one specimen 4.0-8.0 (-16.0) $\mu \mathrm{m}$

- on stipe base-inflated cells, typically subglobose $(55.0 \times 50.0 \mu \mathrm{m})$ or elongated-clavate (e.g., $50.0 \times 20.0 \mu \mathrm{m})$, pale, thick-walled $(1 \mu \mathrm{m})$; filamentous hyphae 2.0-8.0 $\mu \mathrm{m}$, hyaline, abundant; vascular hyphae $4.0-8.0 \mu \mathrm{m}$, abundant

Partial veil: filamentous hyphae 2.0-7.0 $\mu \mathrm{m}$, abundant, intensely intertwined, branched; inflated elongate-elliptical terminal elements $(100.0 \times 22.0$ $\mu \mathrm{m})$, difficult to locate; vascular hyphae absent

Distribution in Brazil: (states of) Paraná, Rio Grande do Sul, Santa Catarina, São Paulo.

Habitat: often on soil under Pinus spp. (mainly P. elliottii Engelm., and P. taeda L.) natural distribution in North America (Silba 1986) and one of the most frequently planted in Brazil (Zanchetta \& Diniz 2006), but also recorded in Eucalyptus sp. plantation (URM 82988) Podocarpus sp. (SP 307271) and Araucaria sp. (URM 75827). However, the latter two tree species are reported to associate predominantly with arbuscular mycorrhizal fungi (Oliveira \& Ventura 1952; Breuninger et al. 2000; Moreira et al. 2007) and basidiomes of A. muscaria var. flavivolvata may be only occasionally present, although collectors do not mention the presence of Pinus nearby or excavating the rhizosphere where the basidiomes were in order to ascertain the ectomycorrhizal association.

Material examined: BRAZIL. Paraná: Cerro Azul, Fazenda Varanópolis, 19/VII/1985 U. Keutenedjian-Filho (no number) (SP 193903); Rio Grande do Sul: Minas do Leão, Agropecuária Condor, 26/V/2008, V.G. Cortez 

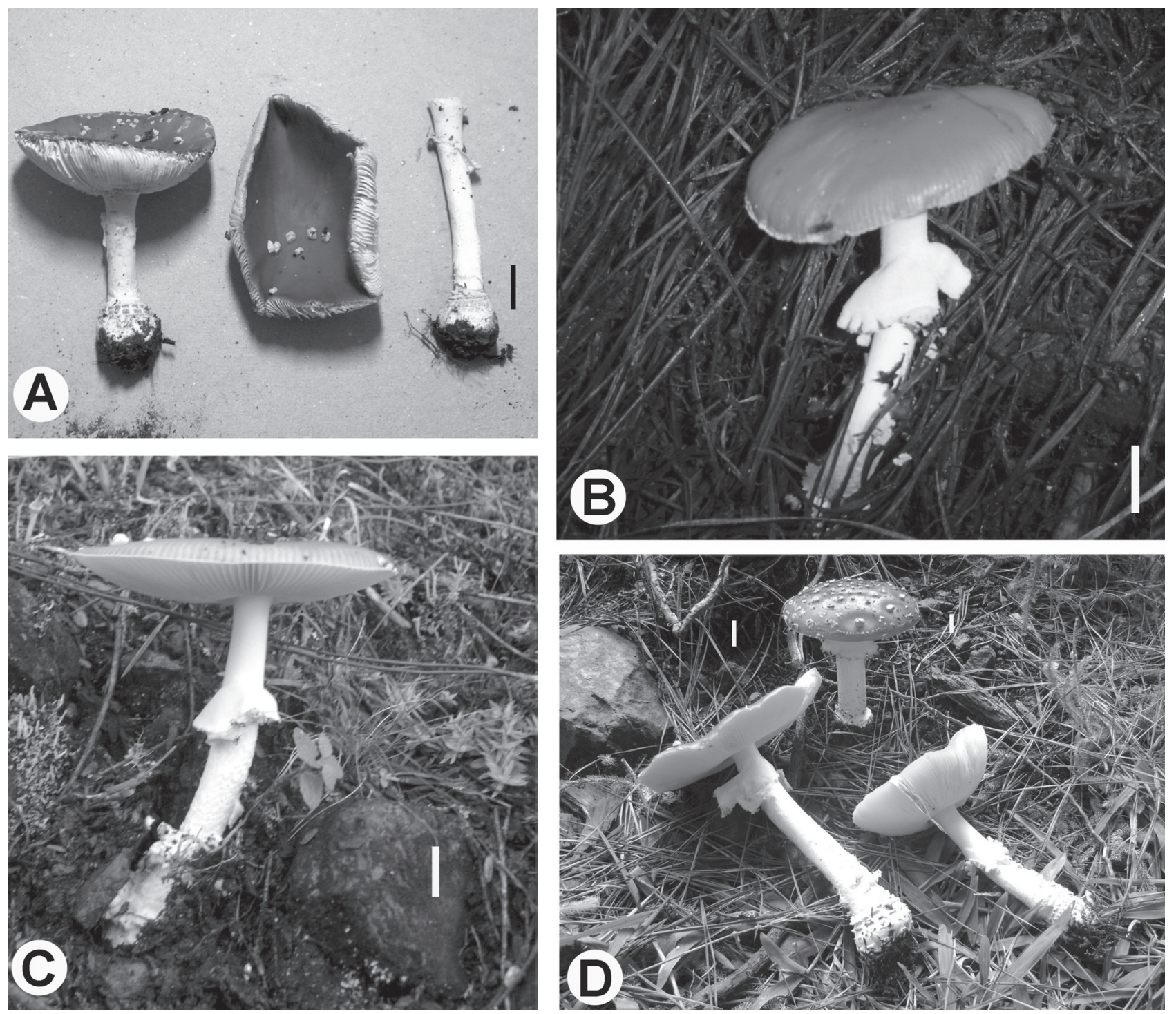

Figure 4. Amanita muscaria var. flavivolvata. A-D, basidiomes. Scale bar $=20 \mathrm{~mm}$. Photographs: A, V.G. Cortez; B, F. Karstedt; C and D, F. Wartchow.

097/08 (URM 82988, RET), Santa Maria, Camobi, Federal University, Santa Maria Campus, 11/VII/2000 V.G. Cortez (no number) (SMDB 9169), São Francisco de Paula National Forest (road leading from entrance to office), 18/V/2009 F. Wartchow FLONA1 (URM 82987, RET), woods within the reserve (behind the office), 18/V/2009, F. Wartchow FLONA4 (URM 82986, RET); Santa Catarina: Joinville, RPPN Caetezal, 24/VIII/2004, F. Karstedt (FURB 840, 425); São Paulo: Campos do Jordão, Horto Florestal at $1350 \mathrm{~m}$ altitude, 28/VI/1997, M.H. Alves (no number) (URM 75827), Campos do Jordão, location unspecified, 12/X/1998, L.K. Okino (no number) (SP 307271).

Note: The macroscopic description of the subspecies is entirely based on collections made by the first author in the São Francisco de Paula National Forest (URM 82987 and URM 82986). Unfortunately, there is no information on collection notes for other records.
Comments: This subspecies, first found in San Francisco, California, was originally named for its yellowish volva (Singer 1958), and the name continued to be used by other authors in North America (e.g. Jenkins 1977, 1986; Thiers 1982) and Europe (Poumarat \& Neville, 2001, 2004). Nevertheless, the color of the volva does not appear to be crucial to the definition of this subspecies. Jenkins \& Petersen (1976) described a neotype of A. muscaria var. muscaria as having a cream-colored to yellowish volva, which raised the possibility that the entity A. muscaria var. flavivolvata occurs in Europe as well (Neville \& Poumarat 2004).

Recent studies show that the most prominent features in distinguishing among these taxa are the $\mathbf{L}^{\prime}$ and $\mathbf{Q}^{\prime}$ of basidiospores, which are reported to be $\mathbf{L}=10.8 \mu \mathrm{m}$ and $\mathbf{Q}^{\prime}=1.42$ in the American subspecies and $\mathbf{L}^{\prime}=10 \mu \mathrm{m}$ and $\mathbf{Q}^{\prime}=1.34$ in the European subspecies (Tulloss, unpublished data; Tulloss \& Yang 2012). Basidiospore data provided by Tulloss (unpublished data) for A. muscaria var. flavivolvata 
are as follows: [957/48/37] (7.5-) 9.0-12.8 (-19.0) $\times(5.5-)$ 6.5-8.5 (-11.5) $\mu \mathrm{m} \mathbf{L}=(8.9-)$ 9.41-12.1 (-14.6) $\mu \mathrm{m} \mathbf{L}^{\prime}=10.8$ $\mu \mathrm{m}, \mathbf{W}=(6.6-) 6.9-8.2 \mu \mathrm{m}(-8.4), \mathbf{W}^{\prime}=7.6 \mu \mathrm{m}, \mathrm{Q}=(1.11-)$ 1.26-1.67 (-2.23), $\mathbf{Q}=(1.29-)$ 1.31-1.65 (-1.95), $\left.\mathbf{Q}^{\prime}=1.42\right)$. Other important features in the differentiation among subspecies are the $\mathbf{w}_{\mathrm{st}}$-near -and $\mathbf{w}_{\mathrm{st}}$ - $\mathbf{f a r}$ of the subhymenium, on which A. muscaria var. muscaria are higher than the American strain of.

Apparently, information about the color of the volva and pileus are of little relevance, because it can be influenced by the climatic conditions to which the basidiomes are submitted. Those conditions can generate yellow or albino forms of pileus within each population (Geml et al. 2008). Fungal pigments include muscaflavin, which produces yellow; muscarine, which produces an orange-red color; muscapurpurin, which produces purple; and muscaaurin, which produces reddish-brown (Meléndez-Michelot \& Howell 2003). The mixture or suppression of certain chemical components can determine what color prevails in a fungus, such as the yellow in the pilei of certain populations in the northeastern United States, which must be attributable to an abundance of muscaflavin.

Amanita muscaria var. flavivolvata is found in proximity to exotic plantations introduced into Australia (Sawyer et al. 2001), Chile (Garrido 1986) and Colombia (Tulloss et al. 1992); in Costa Rica, it is reported as occurring associated with Quercus (Tulloss et al. 2011). Daniele et al. (2005) cited A. muscaria in association with Cedrus Deodara (Roxb. ex D. Don) G. Don in Argentina, although the authors did not mention the infrageneric group to which it belongs. As demonstrated in the present study, A. muscaria var. flavivolvata occurs in the Brazilian states of Parana, Rio Grande do Sul, Santa Catarina and São Paulo. Specimens collected in Brazil by Guerrero \& Homrich (1983), Fusco-Mucci \& Yokomizo (1985), Figueiredo et al. (1996), Giachini et al. (2000, 2004), Meijer $(2001,2006)$ and Sobestiansky (2005) might represent $A$. muscaria var. flavivolvata, because the specimens were found primarily in proximity to P. elliottii and P. taeda, two species imported from North America. The material
F. Karstedt 425 (FURB 840) certainly matches the voucher for the material cited in Karstedt \& Stürmer (2008). One of the specimens examined here (V.G. Cortez 097/08; URM 82988, RET) was collected under a Eucalyptus sp. It is of note that $A$. muscaria sensu lato has often been cited in Australia, albeit associated with exotic plantations (Reid 1979; Grgurinovic 1997, Wood 1997; Hawkeswood 2006, Robinson 2010). However, a study conducted by Malajczuk et al. (1982) demonstrated that this species, in its broader sense, is also associated with Eucalyptus.

The dichotomous key recently proposed by Menolli et al. (2009) emphasizes the yellow color of the universal veil elements in early development as a means of distinguishing A. muscaria var. flavivolvata from A. muscaria var. muscaria. Poumarat \& Neville (2004) also considered the conditions of the universal veil a major distinguishing feature in $A$. muscaria. However, we consider the features of the universal veil irrelevant because they can result merely from environmental conditions to which the basidiome was submitted. The most important features distinguishing A. muscaria var. muscaria from A. muscaria var. flavivolvata are the depth of the subhymenium, the size of the basidiospores, and the geographic distribution (Tulloss \& Yang 2012; Tulloss, personal communication). We have devised a new dichotomous key that focuses on characteristics that are more appropriate to differentiating between the two A. muscaria subspecies in Brazil (Table 1).

In agreement with our interpretation, Geml et al. (2008) suggested that clades corresponding to A. muscaria var. muscaria and A. muscaria var. flavivolvata belong to distinct phylogenetic species. In addition, Vellinga et al. (2009) called for more detailed taxonomic studies in order to elucidate which A. muscaria sensu lato occurs in the southern hemisphere.

\section{Acknowledgments}

We are extremely grateful to Dr. Rodham E. Tulloss, of Roosevelt, New Jersey, for his valuable guidance and friendship, as well as for affording the first author the op-

Table 1. Dichotomous key to the Amanita muscaria subspecies occurring in Brazil.

\begin{tabular}{|c|c|c|}
\hline Characteristic & A. muscaria var. muscaria & A. muscaria var. flavivolvata \\
\hline \multicolumn{3}{|l|}{ Subhymenium } \\
\hline $\mathbf{w}_{\mathrm{st}}-$ near, $\mu \mathrm{m}$ & $110.0-125.0$ & $75.0-90.0$ \\
\hline $\mathrm{w}_{\mathrm{st}}$-far, $\mu \mathrm{m}$ & $130.0-145.0$ & $80.0-100.0$ \\
\hline Basidiospores, $\mu \mathrm{m}$ & $(8.5-) 9.0-12.2(-13.0) \times(5.7-) 6.5-9.3(-9.4)$ & $(8.2-) 8.5-13.7(-14.0) \times(5.5-) 6.0-9.5(-10.0)$ \\
\hline $\mathbf{L}^{\prime}, \mu \mathrm{m}$ & 10.2 & 10.7 \\
\hline $\mathbf{W}^{\prime}, \mu \mathrm{m}$ & 7.6 & 7.6 \\
\hline 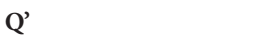 & 1.35 & 1.43 \\
\hline Species in proximity & Castanea sativa & Pinus spp.* \\
\hline
\end{tabular}

$\mathbf{w}_{\mathrm{st}}$-near - distance from one side of the central stratum to the base of the nearest basidium; $\mathbf{w}_{\mathrm{st}}$-far - distance from one side of central stratum to the base of the farthest basidium; L' - the average length of all basidiospores; W' - the average width of all basidiospores; Q' - the mean ratio of length to width computed for all basidiospores of all basidiomes.

* - natural distribution in North America. 
portunity to visit and review his herbarium and examine exsiccates of Amanita from various parts of the world. We also thank the curators of the following herbaria who kindly allowed us to examine exsiccates of Amanita muscaria sensu lato: Adriana M. Gugliotta (SP); Clarice Loguercio-Milk (FLOR); Mara R. Ritter (ICN); Lucy Sevegnani (FURB); Thais S. Canto-Dorow (SMDB); and Jair Putzke (HCB). In addition, we thank the researchers Mara Rosa B. Silveira, Mateus A. Reck, Paula S. Silva and Gilberto Coelho for their assistance in collecting the specimens; Drs. Aristotle Goes-Neto, Iuri G. Baseia, José L. Bezerra, Laise H. Cavalcanti and Gilberto Coelho for reading and making suggestions to improve the draft of the manuscript; and Dr. Vagner Gularte Cortez and Fernanda Karstedt for authorizing the use of their photographs. This work received financial support from the Brazilian Conselho Nacional de Desenvolvimento Científico e Tecnológico (CNPq, National Council for Scientific and Technological Development; PROTAX Grant no. 141073/2006-3 and INCT Herbário Virtual Grant no. 573.883/2008-4) and from the Fundação de Amparo à Ciência e Tecnologia de Pernambuco (FACEPE, Foundation for the Advancement of Science and Technology in the State of Pernambuco; Grant no. 0100-2.03/09 BFP).

\section{References}

Bas, C. 1969. Morphology and subdivision of Amanita and a monograph on its section Lepidella. Persoonia 5: 285-579.

Beardslee, H.C. 1905. The Amanitas of Sweden. Journal of Mycology 11(5): 212-216.

Breitenbach, J. \& Kränzlin, F. 1995. Fungi from Switzerland. IV. Part 2. Mykologia Lucerne, Lucerne.

Breuninger, M.; Einig, W.; Magel, E.; Cardoso, E. \& Hampp, R. 2000. Mycorrhiza of Brazil pine (Araucaria angustifolia [Bert.] O. Ktze.). Plant Biology 2(1): 4-10.

Brough, J. 1971. Soma and "Amanita muscaria". Bulletin of the School of Oriental African Studies, University of London 34(2): 331-362.

Brvar, M.; Možina, M. \& Bunc, M. 2006. Prolonged psychosis after Amanita muscaria ingestion. Wiener Klinische Wochenschrift 118(9-10): 294-297.

Castro, M.L. 1996. Catálogo del género Amanita Pers. ex Hook. (Agaricales) en Galicia (España). Annales Jardín Botánico de Madrid 54: 61-67.

Corner, E.J.H. \& Bas, C. 1962. The genus Amanita in Singapore and Malaya. Persoonia 2: 241-304.

Daniele, G.; Becerra, A. \& Crespo, E. 2005. Amanita muscaria (Basidiomycota) y su asociación micorrícica com Cedrus deodara (Pinaceae) en las Sierras de Córdoba, Argentina. Boletín de la Sociedad Argentina de Botánica 40: 45-49.

Dobrovolski, R.; Both, R.; Coelho, I.P.; Stolz, J.F.B.; Schüssler, G.; Rodrigues, G.G.; Guerra, T. \& Hartz, S.M. 2006. Levantamento de áreas prioritárias para a concervação da Floresta Nacional de São Francisco de Paula (RS, Brasil) e seu entorno. Revista Brasileira de Biociências 4(1): 7-14.

Dunn, E. 1974. Use of Amanita muscaria: a footnote to Wasson's Soma. Currrent Anthropology 14(4): 488-492.

Figueiredo, M.B.; Carvalho Jr., A.A.; Coutinho, L.N. \& Fusco-Mucci, E.S. 1996. Amanita muscaria (L.: Fr.) Hooker, cogumelo de aparência atrativa, mas tóxico. O Biológico 58: 1-5.

Fusco-Mucci, E.S. \& Yokomizo, N.K.S. 1985. Ocorrência de Amanita em plantações de Pinus no estado de São Paulo. Fitopatologia Brasileira 10: 340 .
Garrido, N. 1986. Survey of ectomycorrhizal fungi associated with exotic forests trees in Chile. Nova Hedwigia 43(3-4): 423-442.

Geml, J.; Laursen G.A.; O'Neill, K.; Nusbaum, H.C. \& Taylor, D.L. 2006. Beringian origins and cryptic speciation events in the fly agaric (Amanita muscaria). Molecular Ecology 15(1): 225-239.

Geml, J.; Tulloss, R.E.; Laursen, G.A.; Sazanova, N.A. \& Taylor, D.L. 2008. Evidence for strong inter- and intracontinental phylogeographic structure in Amanita muscaria, a wind-dispersed ectomycorrhizal basidiomycete. Molecular Phylogenetic and Evolution 48(2): 694-701.

Geml, J.; Tulloss, R.E.; Laursen, G.A.; Sazanova, N.A. \& Taylor, D.L. 2009. Phylogeographic Analyses of a Boreal-Temperate Ectomycorrhizal Basidiomycete, Amanita muscaria, Suggest Forest Refugia in Alaska during the Last Glacial Maximun. Pp. 173-186. In: Habel, J.C. \& Assmann, T. (Eds.). Phylogeography and Conservation Biology. Berlin, Springer-Verlag.

Giachini, A.J.; Oliveira, V.L.; Castellano, M.A. \& Trappe, J.M. 2000. Ectomycorrhizal fungi in Eucalyptus and Pinus plantations in southern Brazil. Mycologia 92(6): 1166-1177.

Giachini, A.J.; Oliveira, V.L. \& Souza, L.A.B. 2004. Species richness and seasonal abundance of ectomycorrhizal fungi in plantation of Eucalyptus dunnii and Pinus taeda in Southern Brazil. Mycorrhiza 14(6): 375-381.

Grgurinovic, C.A. 1997. Larger Fungi of South Australia. The Botanic Gardens of Adelaide and State Herbarium \& The Flora and Fauna of South Australia Handbooks Committee, Adelaide.

Guerrero, R.T. \& Homrich, M.H. 1983. Fungos Macroscópicos comuns no Rio Grande do Sul - Guia para Identificação. Porto Alegre, Editora da UFRGS.

Hajicek-Dobberstein, S. 1995. Soma siddhas and alchemical enlightenment: psychedelic mushrooms in Buddhist tradition. Journal of Ethnopharmacology 48(2): 99-118.

Härkönen, M.; Saarimäki, T. \& Mwasumbi, L. 1994. Tanzanian mushrooms and their uses 4. Some reddish edible and poisonous Amanita species. Karstenia 34: 47-60.

Hawkeswood, D.J. 2006. A record of Amanita muscaria (L.) Lam. (Basidiomycetes: Amanitaceae) from Wentworth Falls, New South Wales, Australia with a review of some literature on the ecology of the species within Australia. Calodema 7: 29-31.

Homrich, M.H. 1965. Nota sobre Amanita muscaria (L. ex Fr.) Pers. ex Hooker no planalto Riograndense. Sellowia 17(1): 77-78.

Jenkins, D.T. 1977. A taxonomic and nomenclatural study of the genus Amanita section Amanita for North America. Bibliotheca Mycologica 57: 1-126.

Jenkins, D.T. 1986. Amanita of North America. Eureka. Mad River Press.

Jenkins, D.T. \& Petersen, R.H. 1976. A neotype specimen for Amanita muscaria. Mycologia 68(3): 463-469.

Karstedt, F. \& Stürmer, S.L. 2008. Agaricales em áreas de Floresta Ombrófila Densa e plantações de Pinus no Estado de Santa Catarina, Brasil. Acta Botanica Brasilica 22(4): 1036-1043.

Kirk, P.M. \& Ansell A.E. 1992. Authors of Fungal names. Index of Fungi Supplement. Kew, CAB Internacional.

Krogsgaard-Larsen, P.; Brehm, L. \& Schaumburg, K. 1981. Muscimol, a psychoactive constituent of Amanita muscaria, as a medicinal chemical model structure. Acta Chemica Scandinavica 35(5): 311-234.

Lampe, K.F. 1979. Toxic Fungi. Annual Review of Pharmacology and Toxicology 19: 85-104.

Longhi, S.J.; Brena, D.A.; Gomes, J.F.; Narvaes, I.S.; Berger, G. \& Soligo, A.J. 2006. Classificação e caracterização de estágios sucerssionais em remanescentes de Floresta Ombrófila Mista na FLONA de São Francisco de Paula, RS, Brasil. Ciência Florestal 16(2): 113-125.

Lowy, B. 1974. Amanita muscaria and the thunderbolt legend in Guatemala and Mexico. Mycologia 66(1): 188-191.

Malajczuk, N.; Molina, R. \& Trappe, J.M. 1982. Ectomycorrhiza formation in Eucalyptus. I. Pure culture synthesis, host specificity and mycorrhizal compatibility with Pinus radiate. New Phytologist 91: 467-482.

Mattock, G. 1995. Some notes on Amanita in Hampshire. Mycologist 9(1): 15-17.

Meijer, A.A.R. de. 2001. Mycological work in the Brazilian state of Paraná. Nova Hedwigia 72(1-2): 105-159. 
Meijer, A.A.R. de. 2006. A preliminary list of the Macromycetes from the Brazilian State of Paraná. Boletim do Museu Botânico Municipal (Curitiba) 68: 1-55.

Menolli Jr., N.; Capelari, M. \& Baseia, I.G. 2009. Amanita viscidolutea, a new species from Brazil with a key to Central and South American species of Amanita section Amanita. Mycologia 101(3): 395-400.

Michelot, D. \& Melendez-Howell, L.M. 2003. Amanita muscaria: chemistry, biology, toxicology and ethnomycology. Mycological Research 107(2): 131-146.

Moreira, M.; Baretta, D.; Tsai, S.M., Gomes-da-Costa, S.M. \& Cardoso, E.J.B.N. 2007. Biodiversity and distribution of arbuscular mycorrhizal fungi in Araucaria angustifolia forest. Scientia Agricola 64(4): 393-399.

Neville, P. \& Poumarat, S. 2001. Études sur les variations européenes du complexe d'Amanita muscaria. Bulletin Triméstriél de la Société Mycologique de France 117(3/4): 277-381.

Neville, P. \& Poumarat, S. 2001. Étude sur les variations européennes du complexe d'Amanita muscaria. Bulletin Trimestriel de la Société Mycologique de France 117(3/4): 277-381.

Oda, T.; Tanaka, C. \& Tsuda, M. 2004. Molecular phylogeny and biogeography of the widely distributed Amanita species, A. muscaria and A. pantherina. Mycological Research 108(8): 885-896.

Oliveira, M. \& Ventura, A. 1952. Ocorrência de micorrhiza em Araucaria angustifolia (Bertol.) O. Ktze. e Podoscarpus lambertii. São Paulo, Serviço Florestal.

Pearson, A.A. 1950. Cape Agarics and Boleti. Transactions of the British Mycological Society 33(3-4): 276-316.

Reid, D.A. 1979. A monograph of the Australian species of Amanita Persoon ex Hooker (Fungi). Austalian Journal of Botany Supplementary Series 8: 1-96.

Reid, D.A. \& Eicker, A. 1991. South African fungi: the genus Amanita. Mycological Research 95(1): 80-95.

Ribeiro, S.B.; Longhi, S.J.; Brena, D.A. \& Nascimento A.R.T. 2007. Diversidade e classificação da comunidade arbórea da Floresta Ombrófila Mista da FLONA de São Francisco de Paula, RS. Ciência Florestal 17(2): 101-108.

Ridley, G.S. 1991. The New Zealand species of Amanita (Fungi: Agaricales). Australian Systematic Botany 4(2): 325-354.

Robinson, R. 2010. First record of Amanita muscaria in Western Australia. Australasian Mycologist 29: 5-6.

Rossmeisl Jr., J.H.; Higgins, M.A.; Blodgett, D.J.; Ellis, M. \& Jones, D.E. 2006. Amanita muscaria toxicosis in two dogs. Journal of Veterinary Emergency and Critical Care 16(3): 208-214.

Saar, M. 1991. Fungi in Khanty folk medicine. Journal of Ethnopharmacology 31(2): 175-179.

Samorini, G. 1992. The oldest representation of hallucinogenic mushrooms in the world (Sahara Desert, 9000-7000 B.P.). Integration 2/3: 69-78.

Satora, L.; Dorota, P.; Butryn, B.; Hydzik, P. \& Balicka-Ślusarczyk B. 2005. Fly agaric (Amanita muscaria) poisoning, case report and review. Toxicon 45(7): 941-943.

Sawyer, N.A.; Chambers, S.M. \& Cairney, J.W.G. 2001. Distribution and persistence of Amanita muscaria genotypes in Australian Pinus radiata plantation. Mycological Research 105(8): 966-970.

Silba, J. 1986. Encyclopaedia Coniferae. Phytologia Memoirs 8: 1-217.

Singer R. 1958 ('1957'). Fungi mexicani, series prima. Agaricales. Sydowia 11(1-6): 354-374.

Sobestiansky, G. 2005. Contribution to a Macromycete survey of the states of Rio Grande do Sul and Santa Catarina in Brazil. Brazilian Archives of Biology and Technology 48(3): 437-457.
Stevenson, G. 1962. The Agaricales of New Zealand: II. Kew Bulletin 16(1): 65-74.

Stijve, T. \& Meijer, A.A.R. 1993. Macromycetes from the State of Paraná, Brazil. 4. The Psychoactive species. Arquivos de Biologia e Tecnologia 36(2): 313-329.

Thiers, B. 2012. Index Herbariorum: A global directory of public herbaria and associated staff. New York Botanical Garden's Virtual Herbarium. <http://sweetgum.nybg.org/ih/> (Acesso em 10/01/2012).

Thiers, H.D. 1982. The Agaricales (Gilled Fungi) of California. 1. Amanitaceae. Eureka, Mad River Press.

Trappe, J.M. 1962. Fungus associates of ectotrophic mycorrhizae. Botanical Review 28(4): 538-606.

Tsujikawa, K.; Kuwayama, K.; Miyaguchi, H.; Kanamori, T.; Iwata, Y.; Inoue, H.; Yoshida, T. \& Kishi, T. 2007. Determination of muscimol and ibotenic acid in Amanita mushrooms by high-performance liquid chromatography and liquid chromatography-tandem mass spectrometry. Journal of Chromatography B 852(1-2): 430-435.

Tulloss, R.E. 2000. Note sula metodologia per lo studio del genere Amanita (Agaricales). Bolletino del Gruppo Micologico G. Bresadola, Nuova Serie 43(2): 41-58.

Tulloss, R.E. \& Lindgren, J.E. 2005. Amanita aprica-a new toxic species from western North America. Mycotaxon 91: 193-205.

Tulloss, R.E. \& Yang, Z.-L. 2012. Studies in Amanitaceae. <http://www. amanitaceae.org > (Acesso em 10/01/ 2012).

Tulloss, R.E.; Ovrebo, C.L. \& Halling, R.E. 1992. Studies in Amanita (Amanitaceae) from Andean Colombia. Memoirs of the New York Botanical Garden 66: 1-46.

Tullos, R.E.; Halling, R.E. \& Mueller, G.M. 2011. Studies in Amanita (Amanitaceae) of Central America. 1. Three new species from Costa Rica and Honduras. Mycotaxon 117: 165-205.

Vaasma, M. 2009. Checklist of the species of the genera Amanita and Limacella (Agaricomycetes) in Estonia. Folia Cryptogamica Estonica 45: 81-85.

Vellinga, E.C.; Wolfe, B.E. \& Pringle, A. 2009. Global patterns of ectomycorrhizal introductions. New Phytologist 181(4): 960-973.

Wartchow, F. \& Maia, L.C. 2007. The Neotropical Amanita crebresulcata Bas: new citation from Northeast Brazil. Hoehnea 34(2): 131-134.

Wartchow, F.; Maia, L.C. \& Cavalcanti, M.A.Q. 2013. Studies on Amanita (Agaricomycetidae, Amanitaceae) in Brazil: two yellow gemmatoid taxa. Nova Hedwigia 96(1-2): 61-71.

Wartchow, F., Tulloss, R.E. \& Cavalcanti, M.A.Q. 2007. Discovery of Amanita lilloi in Brazil. Mycotaxon 99: 167-174.

Wartchow, F., Tulloss, R.E. \& Cavalcanti, M.A.Q. 2009. Amanita lippiaea new species from semi-arid caatinga region of Brazil. Mycologia 101(6): 864-870.

Whelan, C. 1974. "Amanita muscaria": the gorgeous mushroom. Asian Folklore Studies 53(1): 163-167.

Wieland, T. 1968. Poisonous principles of mushrooms of the genus Amanita. Science 159: 946-952.

Wood, A.E. 1997. Studies in the genus Amanita (Agaricales) in Australia. Australian Systematic of Botany 10(5): 723-854.

Yang, Z.-L. 1997. Die Amanita-Arten von Südwestchina. Bibliotheca Mycologica 170: 1-240.

Zanchetta, D. \& Diniz, F.V. 2006. Estudo da contaminação biológica por Pinus spp. em três diferentes áreas na estação Ecológica de Itirapina (SP, Brasil). Revista do Instituto Florestal 18: 1-14. 